\title{
CONFLITOS SOCIOAMBIENTAIS ENVOLVENDO A PESCA ARTESANAL NA BAÍA DE ILHA GRANDE - RIO DE JANEIRO
}

\section{ENVIRONMENTAL CONFLICTS INVOLVING ARTISANAL FISHERMEN INTHE ILHA GRANDE BAY - RIO DE JANEIRO}

\author{
Fátima Karine Pinto Joventino* \\ Rosa Maria Formiga Johnsson**
}

\section{Introdução}

0 presente artigo tem por objetivo identificar e caracterizar os principais problemas e conflitos envolvendo a pesca artesanal na Baía de Ilha Grande - BIG, localizada ao sul do estado do Rio de Janeiro. Nesta pesquisa, foi considerado o pescador localizado na zona costeira da Baía de Ilha Grande, não contemplando, portanto, os pescadores que atuam nas águas continentais (rios, lagos e lagoas). Na zona costeira existe uma diversidade de modalidades de pesca sendo desenvolvidas, porém neste trabalho serão considerados os pescadores artesanais ou de pequena escala, isto é, aqueles que realizam a pesca tanto com o caráter de sub- sistência, quanto para fins comerciais. Em alguns casos, esses pescadores, que se autodenominam "caiçaras" ", têm a maior parte de sua renda oriunda das pescarias e podem praticar atividades complementares à pesca (agricultura e turismo, por exemplo). Eles utilizam embarcações mais rústicas (como botes e canoas produzidas artesanalmente, com até 8 metros) podendo utilizar-se também de embarcações um pouco maiores. Outra característica da pesca artesanal, como aqui entendida, é a de ser praticada nas proximidades da costa, sendo poucos os pescadores que se arriscam a pescar em regiões mais distantes da baía.

A região da Baía de Ilha Grande tem sido foco de políticas de preservação, já

\footnotetext{
* Doutora em Ciências pelo Programa de Pós-Graduação em Meio Ambiente da Universidade do Estado do Rio de Janeiro - UERJ. Extensionista da Fundação Instituto de Pesca do Estado do Rio de Janeiro - FIPERJ (Rio de Janeiro/RJ/BR). E-mail: karine.fiperj@gmail.com

${ }^{* *}$ Doutora em Ciências e Tecnologias Ambientais pela Université de Paris XII.Professora adjunta do Departamento de Engenharia Sanitária e do Meio Ambiente da Universidade do Estado do Rio de Janeiro UERJ (Rio de Janeiro/RJ/BR). E-mail: formiga.uerj@gmail.com

1. Os "nativos" da Baía de Ilha Grande são popularmente conhecidos como caiçaras. Segundo a literatura, trata-se de uma cultura oriunda da miscigenação do indígena com o colonizador português e, em menor grau, do escravo africano, que habita a costa entre os estados do Paraná e o Rio de Janeiro (DIEGUES, 2004).
} 
que contém grande parte dos remanescentes de mata atlântica do estado do Rio de Janeiro e uma das áreas mais ricas em temos de biodiversidade. A região integra o Corredor da Biodiversidade da Serra do Mar e foi considerada pelo Ministério do Meio Ambiente, no âmbito do Projeto de Conservação e Utilização Sustentável da Diversidade Biológica Brasileira (PROBIO), um ecossistema de extrema prioridade para a conservação, utilização sustentável e repartição dos benefícios da biodiversidade (MMA, 2002).

Em virtude da beleza paisagística da região, a principal vocação natural está concentrada no turismo e lazer náutico (CREED et al., 2007). Em decorrência disto, uma série de empreendimentos imobiliários ocupa as encostas, margens dos rios e/ou ilhas, provocando o aterro de áreas de manguezais, o desmatamento e a poluição das águas costeiras. 0 crescimento da região como pólo turístico tem promovido um desenvolvimento desordenado, além dos severos danos provocados aos sistemas costeiros.

Além da reconhecida importância em termos de potencialidades naturais, a Baía de Ilha Grande também constitui um pólo de desenvolvimento econômico para o estado do Rio de Janeiro, já que se desenvolvem, ao mesmo tempo, diversos tipos de atividades e empreendimentos de grande porte, que detêm significativa influência sobre a socioeconomia local (o estaleiro BrasFELS, o porto de Angra dos Reis, as usinas nucleares da Eletrobras e o terminal de petróleo TEBIG-Petrobrás, por exemplo). Outras atividades de grande relevância são o turismo (barcos de passeio, lazer e mergulho livre), a pesca (amadora, artesanal e industrial) e a maricultura (cultivo de organismos marinhos).
No que se refere aos diversos tipos de usos e impactos, vale mencionar também a construção da BR 101, conhecida como rodovia Rio-Santos. Após a construção desta rodovia, a região passou por um processo desenfreado de especulação imobiliária e inchamento populacional. Segundo Prado (2002), tanto a abertura da BR 101 quanto a presença de grandes empresas na região justificam o surgimento de empreendimentos imobiliários, traduzidos na construção de inúmeros condomínios e hotéis. 0 afluxo de pessoas vindas de fora para trabalhar na construção desses empreendimentos, somado aos que vieram para trabalhar nas empresas (depois de construídas e instaladas), provocou o aumento populacional e inchamento das cidades de forma vertiginosa, principalmente em Angra dos Reis.

Ao mesmo tempo em que a região apresenta os maiores índices de crescimento populacional do estado, sua economia se encontra em fase de transição. Esta realidade estaria associada, segundo o Instituto Brasileiro do Meio-Ambiente - IBAMA (2006), ao abandono de atividades tradicionais como a pesca, a agricultura e a construção naval, em prol de novas fontes de renda, como a construção civil, o turismo e a especulação imobiliária.

A já mencionada construção da BR101 ligando os grandes centros urbanos - Rio de Janeiro e São Paulo - contribuiu para o aumento de fluxo de turistas e urbanização dos municípios litorâneos de Paraty e Angra dos Reis. Assim, o "território” e cultura caiçara passam a sofrer transformações, à medida que interagem mais intensivamente com os centros urbanos. 0 apelo crescente ao consumo, aliado à crise na atividade pesqueira e à impossibilidade de expansão de suas roças, fizeram com que os caiçaras se aproximassem cada vez mais do turista. 
Estudos (IBIO, 2009; BEGOSSI et al., 2010) têm indicado que a pesca artesanal tem cedido espaço ou co-existido com outras atividades, como o turismo. Lopes (2010), por exemplo, revelou em sua pesquisa que a grande maioria dos pescadores da Baía de Ilha Grande exerce outras profissões além da pesca, sendo as atividades relacionadas (direta e indiretamente) ao turismo consideradas mais relevantes, embora haja pequenas distinções entre as regiões de Angra dos Reis, Ilha Grande e Paraty.

Neste cenário, a diversidade dos usos e de atores sociais, com seus distintos projetos e interesses, têm levado a um progressivo aumento dos conflitos relacionados às diferentes formas de apropriação dos recursos naturais nessa região, em especial, no ambiente marinho. A atividade pesqueira (tanto a artesanal quanto a industrial) constitui um dos principais atores diretamente envolvidos nesta problemática.

0 artigo apresentará inicialmente uma sintese geral dos conflitos e atores identificados neste estudo, tendo como base a percepção dos pescadores. Em seguida, os conflitos serão apresentados em mais detalhes, a partir de três grandes categorias de classifıcação, quais sejam: i) conflitos resultantes da sobreposição dos territórios de pesca/ pesqueiros e áreas protegidas, principalmente aqueles relacionados à Estação Ecológica de Tamoios-ESEC Tamoios; ii) conflitos associados à pesca industrial (identificados como "barcos de fora" pelos pescadores); e iii) conflitos resultantes da falta de regularização/permissionamento da atividade.
As ferramentas metodológicas da pesquisa envolveram a observação direta de uma das autoras em diversas reuniões relacionadas a conselhos consultivos e grupos de trabalho em unidades de conservação, em especial os espaços envolvendo a Esec Tamoios, além de apresentações públicas sobre a proposta de "Acordos de Pesca" e audiências públicas. Estes espaços foram acompanhados no período de julho de 2010 a abril de 2013. Utilizou-se também a observação participante em reuniões e oficinas realizadas no âmbito do projeto "GPESCA-BIG". De forma complementar, foram realizadas entrevistas formais e informais e, sobretudo, identificação e análise de documentos, tais como requerimentos, ofícios, manifestos, processos elaborados pelo extinto Ministério da Pesca e Aquicultura - $\mathrm{MPA}^{3}$ e o Ministério do Meio Ambiente - MMA.

\section{Principais conflitos e atores envolvidos}

Conceitos tais como os de vulnerabilidade e conflitos socioambientais estão no cerne do debate ambiental contemporâneo. De uma maneira geral, é possível perceber a partir da literatura que, independentemente do estudo de caso e problema analisado, as principais questões colocadas pelos autores são recorrentes e refletem, na maioria das vezes, as contradições que permeiam os modelos de desenvolvimento por meio dos quais estes conflitos eclodem. Tais contradições estariam ligadas a diversos fatores, dentre os quais, pode-se citar:

2. GPESCA-BIG: Desenvolvimento e Gerenciamento dos Sistemas de Gestão da Aquicultura e Pesca na Baía de Ilha Grande, do qual a autora participou como pesquisadora. Projeto desenvolvido em parceria entre o Núcleo de Solidariedade Técnica - SOLTEC/UFRJ, a Fundação Instituto de Pesca do Estado do Rio de Janeiro - FIPERJ.

3. 0 Ministério da Pesca e Aquicultura - MPA foi extinto em 2015 e atualmente o setor está inserido na Secretaria Especial de Aquicultura e Pesca SEAP/PR, vinculada à Presidência da República. 
a) o papel paradoxal do Estado nas tomadas de decisão e na proteção do bem público/comum; b) os diferentes tipos de interesse e percepção de valor sobre o ambiente; c) os discursos ideológicos e as soluções técnicas determinando as ações e escolhas políticas dos atores; d) os diversos campos de poder (econômico e político) em jogo; e) as análises reducionistas dos danos limitando-se aos aspectos monetários; f) a distribuição desigual das riquezas; g) a externalização dos riscos e danos ambientais às classes menos favorecidas; entre outros (ACSELRAD, 2004, 2005; CARNEIRO, 2005; MARTINEZ-ALIER, 2007; PEREIRA, 2005).

Os conflitos socioambientais estão aqui inseridos no campo de estudo da ecologia política, um campo transdisciplinar de pesquisa que procura integrar aspectos relacionados à ecologia humana e à economia política, abordando de maneira complementar as dimensões sociais e biofísicas. Trata-se ainda de um campo epistemológico em construção, que procura também incorporar a natureza política das relações sociais como instrumento importante de análise dos problemas socioambientais.

Este trabalho se aproxima do conceito de conflitos socioambientais adotado por Litte (2001 e 2006), o qual consiste em um conjunto complexo de embates entre grupos sociais em função de seus distintos modos de inter-relacionamento ecológico. Numa tentativa de facilitar esta identificação, o autor apresenta pelo menos três tipos de conflitos: 1) Conflitos em torno do controle sobre os recursos naturais, como por exemplo, os que envolvem disputas sobre a exploração ou não de minério, da pesca, do uso dos recursos florestais etc.; 2) Conflitos em torno dos impactos (sociais ou ambientais) gerados pela ação humana, como por exemplo, contaminação dos rios e do ar, desmatamento, construção de barragens hidrelétricas etc.; 3) Conflitos em torno do uso dos conhecimentos, valores e modo de vida, cujo núcleo central reside num choque de valores e ideologias (LITTLE, 2001).

Segundo Little (2006), os conflitos socioambientais se configuram não apenas como um campo de estudo, mas também de ação política. Numa perspectiva sobre o método dos estudos inseridos no paradigma ecológico, o autor delimita/estabelece o subcampo da etnografia dos conflitos socioambientais $^{4}$, como segue: A mesma escolha de "etnografar" um confli-
to determinado representa uma decisão polí-
tica e, no processo, transforma um problema
social num tema de análise científica. Na ex-
ploração das implicações conceituais de pro-
blemas sociais, a pesquisa em ecologia políti-
ca não apenas contribui para a compreensão
do conflito, mas "visibiliza” atores socioam-
bientais marginalizados e revela conexões e
relações de poder antes ignorados. Esse co-
nhecimento, por sua vez, contém o poten-
cial de ser apropriado pelos próprios atores
sociais e pode provocar um questionamento
de políticas públicas vigentes e propostas de
novos tipos de ação e controle público. (LI-
TLLE, 2006, p. 98)

4. Segundo o autor, a etnografia dos conflitos socioambientais difere da etnografia tradicional, uma vez que: a) o foco de análise não reside em um grupo social específico, mas sim na análise dos conflitos socioambientais em si e suas múltiplas interações que o fundamentam; b) não está em análise um grupo social apenas, mas também vários grupos sociais; c) o escopo geográfico é raramente limitado ao escopo local do grupo, já que incorpora vários níveis de articulação social. 
Um aspecto importante ao se analisar tais conflitos refere-se à identificação e categorização dos atores sociais (stakeholders) envolvidos no sistema de gestão em análise: seus diversos interesses e cotas de poder (formais ou informais). 0 quadro a seguir apresenta uma sintese dos principais atores envolvidos (direta e indiretamente) em conflitos com a pesca artesanal na Baía de Ilha Grande, bem como uma breve descrição sobre o papel desempenhado por estes nos conflitos identificados pela pesquisa.

Quadro 1 - Síntese dos principais atores/instituições envolvidos em conflitos com a pesca artesanal na Baía de Ilha Grande

Atores direta e indiretamente implicados nos conflitos

Atores

Pescadores artesanais

Colônia de pescadores Z-18, Paraty

Pesca industrial

Operadoras de turismo

Instituto Chico

Mendes de Conservação da Biodiversidade

(ICMBio)

\section{Descrição}

Objeto de estudo em análise: pescadores artesanais de Angra dos Reis, incluindo parte insular da Ilha Grande e demais ilhas, e Paraty.

Entidade que representa os pescadores artesanais de Paraty. Possui uma participação ativa nos espaços de discussão na região como um todo.

Barcos de grande porte que vêm de outras regiões para pescar na Baía de Ilha Grande. São atuneiros, pesca de cerco e camaroneiras que pescam grandes volumes na BIG, inclusive em áreas protegidas e durante o defeso.

Realizam passeios turísticos em barcos de diversos portes na BIG

Autarquia vinculada ao MMA. Responsável por executar as ações do SNUC, podendo propor, implantar, gerir, proteger, fiscalizar e monitorar as UC's instituídas pela União. Fomento a ações de preservação e conservação da biodiversidade. Tem poder de polícia ambiental para proteção de UC's Federais.

\section{Papel no conflito}

Elemento central dos conflitos em análise. Os conflitos estão relacionados, sobretudo, aos gestores públicos fiscalizadores de áreas protegidas no espaço marinho e também com a pesca industrial. Em alguns casos, são verificados conflitos entre os próprios pescadores artesanais, como na pesca de arrasto. Uma parcela dos artesanais assume pescar em períodos de defeso.

Desempenhou papel importante na politização dos conflitos envolvendo a pesca artesanal e na busca por soluções para o seu enfrentamento. É fortemente articulado com a Câmara de Vereadores do município.

É objeto do conflito para os pescadores artesanais, que termina repercutindo nos órgãos fiscalizadores por não serem estruturados/ capazes de limitar a sua atuação na BIG.

Conflito com os pescadores artesanais na utilização do espaço marinho e recurso pesqueiro, uma vez que também podem realizar a pesca de mergulho.

Órgão responsável pela gestão da principal UC marinha da BIG (ESEC Tamoios), na qual a pesca é proibida num raio de $1 \mathrm{~km}$ ao redor das 29 ilhas que a compõem. Um dos principais atores diretamente implicados nos conflitos, principalmente por exercer a fiscalização ambiental nessas áreas. 
Instituto Brasileiro do Meio Ambiente e dos Recursos Naturais Renováveis (IBAMA)

Instituo Estadual do Ambiente (INEA)

Polícia Florestal e Ambiental

Delegacia da Capitania dos Portos de Angra dos Reis e Agência de Paraty

Ministério da Pesca e Aquicultura - MPA

(atualmente extinto).
Autarquia federal vinculada ao MMA. Há um Escritório Regional desta instituição no município de Angra dos Reis. Responsável pelo monitoramento, controle e fiscalização das atividades que interferem na qualidade ambiental (poder de policia ambiental).

Órgão com a missão de proteger, conservar e recuperar o meio ambiente do estado do Rio de Janeiro. Atua também no âmbito do licenciamento ambiental das atividades industriais e comerciais.

Poder de monitorar, fiscalizar e autuar as atividades humanas.

Organização militar responsável pela segurança do tráfego aquaviário e subordinada à Capitania dos

Portos do RJ.

Órgão responsável pela política, fomento e infraestrutura pesqueira e aquícola nacional. Atribuição de trabalhar em parceira com o MMA na gestão dos recursos pesqueiros e aquícolas.
Principal órgão gestor diretamente implicado nos conflitos, especialmente por exercer a fiscalização ambiental em diversos contextos: durante os períodos de defeso, em áreas de exclusão de pesca e em unidades de conservação.

Órgão gestor diretamente implicado nos conflitos, principalmente por exercer a fiscalização ambiental em parceria com o IBAMA e ICMBio (fiscalização integrada).

Órgão gestor indiretamente implicado nos conflitos, principalmente no apoio à fiscalização integrada com o IBAMA, ICMBio e INEA.

Embora tenha poderes de fiscalização, principalmente no tocante à regularização da embarcação e normas de segurança marítima, não se sobressai como um ator diretamente associado ao conflito como agente fiscalizador.

Tem influência indireta sobre os conflitos, pelos seus poderes normativos, principalmente quanto ao choque de normas entre este órgão e o MPA.

Tem influência indireta sobre os conflitos, principalmente quanto ao choque de normas entre este órgão e a Capitania dos Portos. Entretanto, o conflito mais evidente se refere ao não permissionamento de pescarias realizadas na BIG, tornando os pescadores vulneráveis à fiscalização ambiental.

Não possui poder de fiscalização.

Fonte: Joventino, 2013. 
Como se pode perceber, a partir do quadro acima, há um número significativo de atores envolvidos em conflitos com a pesca artesanal na Baía de Ilha Grande. Como atores diretamente implicados nos conflitos, citam-se os órgãos de proteção do meio ambiente, representados pelo Ibama e ICMBio, autarquias vinculadas ao Ministério do Meio Ambiente. Estas duas instituições têm representação na região e ambas desempenham o papel de proteção da biodiversidade, estando o $\mathrm{ICMBio}^{5}$ diretamente relacionado à gestão das unidades de conservação. Além destes dois órgãos com viés de proteção da natureza, a nível estadual também foi identificado o Instituto Estadual do Ambiente - INEA: são órgãos ambientais que atuam em articulação com a Polícia Florestal Ambiental, e que apareceram como atores diretamente implicados nos conflitos associados à fiscalização ambiental.

Como já mencionado, o ator central a partir do qual os conflitos são caracterizados neste estudo são os pescadores artesanais. Além destes, considerou-se ainda como atores importantes, a Colônia de Pescadores Z-18 e a Câmara Municipal de Paraty, que desempenharam papel significativo no que se refere à explicitação dos conflitos em diversas arenas públicas de discussão e na mobilização do setor. Outro tipo de "resposta" que esses grupos têm dado aos conflitos consiste na ação articulada destas instituições em denúncias e na elaboração de diversos documentos (ofícios, requerimentos e manifestos), os quais desencadearam processos junto ao Ministério do Meio Ambiente e o extinto Ministério da Pesca e Aquicultura - MPA, parte destes apresentados na seção 1.4 do artigo.

\subsection{Síntese dos conflitos}

De maneira geral, os resultados indicam que os problemas levantados pelos pescadores interferem no desenvolvimento da atividade da pesca artesanal na região, e estão todos relacionados entre si, interagindo de forma conflituosa sobre o território marinho da Baía de Ilha Grande. São eles: problemas envolvendo a pesca predatória; fiscalização dos órgãos ambientais; barcos vindos de outras regiões (barcos de "fora”); uso de tecnologias (ecossonda, sonar) para navegação e detecção de cardumes; unidades de conservação; poluição; desrespeito ao período de defeso; dificuldades de obtenção das licenças de pesca; pesca de mergulho, entre outras.

Os problemas se apresentaram como vetores de conflitos envolvendo o setor pesqueiro e demais tipos de usos, embora em escalas distintas de impacto. 0 quadro abaixo associa os objetos de conflito aos problemas levantados pelos pescadores artesanais, identificando os atores envolvidos em cada um deles.

5. Durante a realização desta pesquisa, o ICMBio iniciou um trabalho com a finalidade de se implantar um Termo de Compromisso entre os pescadores artesanais e a Estação Ecológica de Tamoios, mais precisamente nas comunidades de Tarituba e Mangaratiba, visando solucionar parte dos conflitos envolvendo a pesca artesanal na região. 
Objetos de conflito envolvendo a pesca artesanal

Áreas protegidas

"Barcos de fora"

Regularização da atividade

Conflitos entre os próprios pescadores artesanais

Fiscalização ambiental associada a todas as questões acima: UC's, áreas de exclusão de pesca, "barcos de fora” e regularização ambiental.

\section{Problemas associados}

Sobreposição de áreas de unidades de conservação (ESEC Tamoios) e territórios de pesca (pesqueiros)

Áreas de exclusão de pesca (N35 e outras normas)

Disputas por recursos pesqueiros; Pesca em períodos de defeso e em áreas protegidas

Disputas por espaço e recursos pesqueiros

Aumento do tráfego de embarcações off -shore; Operações shiptoship (risco de vazamento de óleo)

Conflitos de normas

Pescadores e embarcações não registradas/inscritas no RGP (registro geral da pesca)

Dificuldade de obtenção de licença/autori- MPA zação para pesca

Pescarias não reconhecidas/permissionadas pelo MPA e MMA (cerco flutuante e pesca de camarão branco em canoas a remo em sistema de emalhe, picaré e puçá);

Pesca predatória

Quando direcionada aos pescadores artesanais ela é considerada abusiva;

É apontada como ineficiente quando direcionada à pesca industrial e outros usos, como pesca amadora/turismo;

Um risco em potencial para as pescarias que ainda não são reconhecidas/permissionadas pelo MPA/MMA.

\section{Atores envolvidos}

IBAMA, ICMBio e INEA

IBAMA, INEA, MPA

Pesca industrial (atuneiros e arrastões)

Operadoras de turismo/pesca amadora.

Petrobrás

Capitania dos Portos e MPA MPA

MMA e MPA (sistema compartilhado de ordenamento)

Pesca de arrasto de camarão

IBAMA, ICMBio, INEA, Polícia Federal/Ambiental (Fiscalização integrada)

Fonte: Joventino, 2013. 
Para fins deste trabalho, agrupamos quase todos os problemas identificados pelos pescadores artesanais (exceto poluição) em três grandes categorias de conflito: 1) Áreas protegidas: os conflitos ocorrem, principalmente, devido à sobreposição de áreas de pesca ("pesqueiros") com unidades de conservação, mas também estão relacionados às áreas de exclusão de pesca (AEP's) criadas a partir de normas de ordenamento pesqueiro, com o objetivo de preservação das espécies; 2) "Barcos de fora": relacionam-se principalmente aos conflitos envolvendo a pesca artesanal e a pesca industrial. Foram constantes as referências aos barcos oriundos de outras regiões, principalmente dos estados de São Paulo e Santa Catarina. A percepção dos pescadores é a de que os barcos realizam pesca predatória no interior da baía, atuando inclusive em áreas protegidas, desrespeitam os períodos de paralisação da pesca (defeso) e utilizam tecnologias pesqueiras de detecção de cardumes (sonda e sonar). Adicionalmente, o termo também esteve associado às embarcações que realizam as atividades ligadas ao setor de petróleo, gás e de turismo; 3) Ordenamento/regularização da atividade: problemas estão associados tanto ao estado de ilegalidade em que se encontram os pescadores da BIG que, em alguns casos, não dispõem de licenças de pesca devido ao não reconhecimento/permissionamento, por parte dos órgãos de gestão e ordenamento pesqueiro (MMA e MPA), de algumas pescarias praticadas regionalmente.

Cabe esclarecer, por outro lado, que a classificação dos conflitos em três grandes grupos não signifıca reduzi-los a três tipos de conflitos. Esta é apenas uma forma de facilitar o seu entendimento e de fornecer subsídios aos encaminhamentos dos problemas apontados pela pesquisa. Considerando as três grandes vertentes, a fis- calização ambiental apareceu de maneira transversal a todas, evidenciando constituir o elo comum entre os conflitos e os atores direta e indiretamente implicados nos mesmos. Ou seja, os conflitos estão relacionados entre si e se traduzem na forma da "fıscalização ambiental". Adicionalmente, a forma diferenciada como a fiscalização ambiental é percebida pelos pescadores artesanais, variando conforme o ator diretamente implicado, pode sinalizar que estão em jogo distintas formas de poder e interesses, em vez de ser exercida de forma igual entre os atores.

Como veremos adiante, no que se refere ao primeiro eixo (áreas protegidas), a fiscalização direcionada aos pescadores artesanais esteve associada a uma abordagem truculenta e impositiva. Ao mesmo tempo em que isso ocorre, a fiscalização também é considerada ineficiente quando (não) aplicada aos "barcos de fora”, em especial à pesca industrial. Em menor escala, ela é tida como um risco em potencial para os pescadores que realizam pescarias ainda não reconhecidas/ permissionadas pelos órgãos de gestão e ordenamento da atividade.

Em síntese, os conflitos estão relacionados tanto ao tipo de prática e uso que se faz sobre o recurso (como quando os pescadores questionam a pesca predatória associada às embarcações de pesca de grande porte, por exemplo), assim como sobre os diferentes modos de representação e significado do "meio", uma vez que os pescadores têm dificuldades de entender porque estão proibidos de pescar em locais onde sempre desenvolveram suas pescarias, tendo como base para isso, essencialmente, seus conhecimentos tradicionais.

Além dos conflitos resultantes das diferentes formas de apropriação do espaço 
marinho (consequentemente, dos recursos pesqueiros), também havia aqueles relacionados ao papel paradoxal do Estado no estabelecimento das regras e normas de ordenamento (incluindo a fiscalização/ monitoramento ambiental), à burocracia e diversas instituições existentes para tratar de problemas comuns, tornado confuso o gerenciamento da atividade. Impasses que, em alguns casos, têm dificultado o acesso dos pescadores às políticas públicas. Nas próximas subseções os conflitos são caracterizados em mais detalhes.

\subsubsection{Pesca artesanal \& áreas protegidas: principal conflito regional}

A Baía de Ilha Grande contém o maior número de Unidades de Conservação (UC's) do território fluminense. Em Angra dos Reis e Paraty, parte das ilhas distribuídas entre os dois municípios está localizada dentro de Unidades de Conservação, a exemplo da área de Proteção Ambiental de Tamoios (APA Tamoios), a APA Cairuçu, o Parque Estadual da Ilha Grande (PEIG) e a Estação Ecológica (ESEC) de Tamoios. Vale mencionar que serão destacados, essencialmente, os conflitos relacionados a esta última (Esec Tamoios), por terem sido apontados pelos pescadores como centrais e cujas normas e zoneamento apresentam-se como uma das mais restritivas no que se refere ao uso e manejo dos recursos naturais.
Segundo o Plano de Manejo da Esec Tamoios (IBAMA, 2006), sua área de influência é defınida pelos limites terrestres e águas jurisdicionais dos municípios de Angra dos Reis e Paraty, acrescida da porção marinha da BIG que não pertence a esses municípios. Em termos gerais, os pescadores afirmam ser favoráveis à existência de áreas protegidas, mas discordam da forma com que essas áreas foram estabelecidas no contexto da BIG. Neste sentido, são comuns questionamentos sobre os critérios de escolha dessas áreas como de proteção ambiental. No caso da Esec Tamoios, especificamente, argumentam que isto teria sido feito de maneira aleatória e sem argumentos técnicos embasados, apenas para efeito de criação das Usinas $\mathrm{Nu}$ cleares de Angra dos Reis ${ }^{6}$.

Em termos gerais, pode-se afirmar que as comunidades de Mambucaba (distrito de Angra dos Reis) e Tarituba (distrito de Paraty) são as que mais sofrem interferência direta da sobreposição de áreas protegidas da Esec, provocadas pela proximidade das ilhas. Essas áreas marinhas protegidas, decorrentes do entorno de $1 \mathrm{~km}$ a partir do limite terrestre das ilhas, resultam na formação de 12 blocos de exclusão à atividade $^{7}$. Alguns destes blocos são formados apenas por uma ilha, e outros por várias ilhas agrupadas devido à sua proximidade (ICMBio, 2009).

A formação de blocos de exclusão de pesca, provocada principalmente pelas

6. Contudo, cabe esclarecer que a obrigação de realização de consulta pública precedendo a criação de unidades de conservação só se deu a partir da promulgação da Lei 9.985/2000 (Lei do SNUC), posterior ao ano de criação da UC em análise. Em seu Capítulo IV (Da criação, implantação e gestão das unidades de conservação), artigo $22 \S 2^{\underline{0}}$ desta Lei determina que “A criação de uma unidade de conservação deve ser precedida de estudos técnicos e de consulta pública que permitam identificar a localização, a dimensão e os limites mais adequados para a unidade, conforme se dispuser em regulamento". Vale ressaltar, porém, que as estações Ecológicas e Reservas Biológicas, como é o caso da Esec Tamoios, estão isentas desta obrigatoriedade, conforme determinado pelo $§ 4^{\circ}$ da mesma lei: “na criação de Estação Ecológica ou Reserva Biológica não é obrigatória a consulta pública” (SNUC, 2000, grifos nossos). 
ilhas que compõem a Esec Tamoios, contribui para que os pescadores percam cada vez mais o espaço disponível às suas atividades. Os problemas são intensificados à medida que, além de não poderem pescar nas proximidades da costa, suas embarcações também não dispõem de autonomia para navegar em áreas mais distantes, pois são do tipo canoas e botes a remo.

A grande maioria dos pescadores afirma estar sendo prejudicada por não poder exercer suas atividades ${ }^{7}$ nestas áreas, locais onde estão localizados alguns dos principais "pesqueiros". ${ }^{8}$ Para eles, é difícil compreender porque "agora" são proibidos de pescar em locais que sempre utilizavam como locais de pesca: "Hoje em dia é difícil entrar na cabeça do pescador que é área protegida...Nasci e me criei pescando, agora diz que é área protegida...então a gente não entende bem isso" ${ }^{\circ}$.

0 acesso aos "pesqueiros", principal fonte de sustento e renda, é comprometido e representa um impasse no desenrolar do conflito. Isto porque, ao mesmo tempo em que as áreas pesqueiras têm significado simbólico, socioeconômico e cultural para os pescadores artesanais locais, também se constituem em importantes áreas de preservação das espécies marinhas. Muitas destas áreas funcionam como importantes berçá- rios de espécies de peixes, que procuram esses ambientes para se alimentar e reproduzir, justificando assim, a importância de se respeitar os limites de zoneamento estabelecidos por essa Unidade de Conservação.

\subsection{2 Áreas de Exclusão de Pesca - AEP}

Os conflitos de usos e normas em relação às práticas de pesca artesanal na BIG são evidenciados não apenas por conta das áreas protegidas que compõem a Esec Tamoios, mas também devido às Áreas de Exclusão de Pesca (AEP), estabelecidas por normas específicas de ordenamento pesqueiro, como por exemplo, a Portaria N-35/1988.

As áreas ou zonas de exclusão de pesca correspondem ao fechamento temporário ou permanente de áreas marinhas, de forma a viabilizar a recuperação e/ou o manejo de estoques pesqueiros de espécies sobre exploradas, visando atingir a sustentabilidade pesqueira ${ }^{10}$. Caracterizam-se por ser locais com restrição total ou parcial à atividade pesqueira, no ambiente costeiro-marinho ou oceânico, e sua aplicação como instrumento de ordenamento da atividade pesqueira está prevista no Plano Estratégico Nacional de Áreas Protegidas - PNAP ${ }^{11}$, segundo o qual, essas zonas têm status de área protegida,

7. 0 bloco de ilhas que apresenta maior percentual de área corresponde às seguintes: (1) Ilhas do Sandri, Algodão e Samambaia (20,28\% total da área da UC), próximas ao distrito de Mambucaba; (2) Ilhas de Araraquara, Araraquarinha, Jurubaía e Rochedo de São Pedro (14,09\% \% total da área da UC), localizados entre Mambucaba e Tarituba; (3) Ilha Comprida, Ilhota Grande, Ilhota Pequena e Laje do Cesto (11\% \% total da área da UC), próximas à Tarituba.

8. Este termo é comumente usado pelos pescadores para se referir aos locais de pesca em que há abundância de peixes e que vêm sendo explorados desde seus antepassados.

9. Pescador de Provetá, entrevista concedida em 16 abr. 2011.

10. Essas áreas são delimitadas por meio de portaria do órgão gestor do meio ambiente integrante do Sistema Nacional de Meio Ambiente - SISNAMA (municipal, estadual ou federal), quando dentro de unidades de conservação de uso sustentável, ou devem ser estabelecidas conjuntamente pelo MMA e pelo Ministério da Pesca e Aquicultura (MPA) dentro da competência conjunta de ordenamento pesqueiro (MMA, 2006).

11. Instituído a partir do Decreto $n^{\circ}$ 5758, de 13 de abril de 2006. 
mas não constituem unidades de conservação (IBIO, 2009; MMA, 2006).

Um exemplo de AEP's existente na BIG que tem provocado diversos conflitos são as normas definidas pela Portaria SUDEPE N-35/1988, a qual proíbe a pesca até a distância dos $1000 \mathrm{~m}$ ao redor ou ao largo das seguintes áreas marinhas: I) Ilha Grande, Ilha da Gipóia, dos Porcos, Sandri, da Barra, Comprida, de Cunhambebe, do Cavaco, da Caieira; e II) Enseadas de Bracuí, da Gipóia, de Sapuíba, e Ariró, pertencentes à Baía da Ribeira. Nestas áreas, é permitida a pesca artesanal ou amadora que utilizem somente linha de mão, ou vara linha e anzol, com ou sem molinete, assim como as atividades de maricultura.

Existem outras normas vigentes ${ }^{12}$ que limitam o acesso e ordenam a pesca nesses locais, a exemplo da Portaria SUDEPE $\mathrm{n}^{\circ}$ $3 / 1987$, que proíbe a pesca de arrasto pelos sistemas de portas e parelhas nos seguintes locais: I) interior do Saco de Mananguá, até a área limitada entre a Ponta da Escalvada e a Ponta do Buraco; II) interior da enseada de Paraty Mirim, até a área limitada entre a Ponta da Aguada e a Ponta da Barra; e III) interior da Baía de Paraty até os limites definidos entre a Ponta do Cavalo, Ponta de Fora da Ilha do Mantimento, Ponta de Fora da Ilha Comprida e a Ponta do Boi no continente.
Os resultados encontrados sugerem que muitos pescadores de Angra dos Reis, por exemplo, parecem não ter clareza sobre as defınições e os limites das áreas de exclusão pesqueira e das áreas protegidas existentes em função das Unidades de Conservação, como aquelas da Esec Tamoios. A sobreposição de normas tem gerado conflitos, dificultando o entendimento dos pescadores também no que se refere às competências e atribuições dos órgãos responsáveis por sua gestão e fiscalização, como o ICMBio e o Ibama, sendo comum considerarem todos como Ibama.

\subsubsection{Operações de fiscalização e a expli- citação do conflito}

As primeiras manifestações públicas evidenciando o conflito entre os pescadores artesanais e a Esec Tamoios ocorreram em 2005, logo após o início das primeiras operações de fiscalização da unidade que, naquele ano, verificam-se ainda com pouca frequência. Foi somente em 2006, após a assinatura de um Termo de Compromisso relativo à Compensação Ambiental da Eletronuclear (Usina de Angra II), que a Esec construiu sua sede própria e adquiriu equipamentos e embarcação para atuar no ambiente marinho e insular (MEMO $\mathrm{n}^{\circ}$ $019 / 2010)^{13}$.

12. Ressalta-se, ainda, a Portaria IBAMA n 43/1994, que proíbe a pesca de arrasto pelos sistemas de portas e parelhas por embarcações maiores de 10 TAB (Toneladas de Arqueação Bruta) nas áreas costeiras do estado do Rio de Janeiro, a menos de 2 (duas) milhas da costa.

13. Como não havia o SNUC na época da instalação da Usina Nuclear de Angra I, a Esec Tamoios não obteve nenhum recurso oriundo de compensação ambiental (medida esta prevista no art. 36 da Lei do SNUC). 0 Art. 36 do SNUC estabelece que: "Nos casos de licenciamento ambiental de empreendimentos de significativo impacto ambiental, assim considerado pelo órgão ambiental competente, com fundamento em estudo de impacto ambiental e respectivo relatório - EIA/RIMA, o empreendedor é obrigado a apoiar a implantação e manutenção de unidade de conservação do Grupo de Proteção Integral, de acordo com o disposto neste artigo e no regulamento desta Lei". 
Segundo entrevista realizada com a chefe da Unidade de Conservação da época, as primeiras operações de fiscalização tiveram uma enorme repercussão na região. Embora a UC existisse desde a década de 1990, a Esec Tamoios passou a ser de conhecimento público somente após o início dessas operações que passaram a ocorrer com maior frequência em 2006, sobretudo durante o período de defeso das espécies ${ }^{14}$. Ainda segundo a entrevistada, a chegada da Polícia Federal e de um analista ambiental do Ibama por volta dos anos de 2006 e 2007, constitui uma marco/divisor de águas para as operações de fiscalização na baía.

Iniciam-se, a partir desse momento, as operações integradas de fiscalização, embora só mais recentemente (2012) tenham ganhado força. A partir de 2013, estas operações passaram a contar também com o apoio das prefeituras municipais, tanto de Angra dos Reis, quanto de Paraty, além do INEA, Polícia Ambiental e os guarda-parques do estado.

Vale ressaltar que a fiscalização ambiental vem sendo percebida de maneira negativa e, ao mesmo tempo, antagônica entre os pescadores artesanais da BIG. Segundo a maioria dos relatos, quando a fiscalização é direcionada à pesca de menor porte, quase sempre ela se dá de forma abusiva pelos agentes de fiscalização. Neste sentido, são comuns queixas sobre a abordagem truculenta adotada pelos fiscais, o uso de armas durante as operações de fiscalização e a apreensão de material de pesca (pescado capturado e petrechos).
Embora os pescadores artesanais considerem a fiscalização ambiental importante, julgam ser necessária a mudança na abordagem que é feita durante as operações. Além disso, argumentam que os fiscais deveriam respeitar o seu conhecimento empírico e tratá-los com mais dignidade, conforme relatos a seguir: "A fiscalização não respeita nós, trata nós como se fosse bandido...eles querem dizer que sabem mais que a gente" ${ }^{15}$; "Os policiais esquecem que temos famílias em casa para alimentar" ${ }^{16}$.

Este tipo de postura contribui para que os pescadores se sintam marginalizados e excluídos socialmente, já que privá-los do acesso ao mar constitui uma afronta à sua identidade: "Você via a lancha e tinha ódio...É a mesma coisa de não deixar você entrar na sua casa!" ${ }^{17}$.

Por outro lado, ao mesmo tempo em que isso acontece, os pescadores relatam que a fıscalização ambiental não é aplicada com o mesmo rigor para os demais tipos de usos da baía (como no caso da pesca industrial, turismo e pesca amadora), argumentando que a fiscalização deveria ocorrer em "condições iguais para todos”.

Embora os pescadores possam ter motivos/razões que reforçam esta percepção negativa de que apenas o segmento social ao qual pertencem vem sendo penalizado pela fiscalização ambiental, vale esclarecer, por outro lado, que essas operações, gradativamente, vêm sendo também direcionadas às demais atividades e usos na BIG. Em algumas reuniões acompanhadas nesta pesqui-

14. 0 periodo de defeso consiste na paralisação temporária da pesca para a preservação da espécie, tendo como motivação a reprodução e/ou recrutamento, bem como paralisações causadas por fenômenos naturais ou acidentes (Lei ${ }^{\circ} 11.959$, de 29 de junho de 2009).

15. Pescador de Provetá - Ilha Grande, entrevista concedida em 16 abr. 2011.

16. Pescador do Frade, Angra dos Reis, entrevista concedida em 3 set. 2011.

17. Presidente da Colônia de Pescadores de Paraty, Z-18, entrevista concedida em 30 abr.2013. 
sa, foram divulgadas, por parte da equipe da Esec, diversas ações, em andamento, de monitoramento e fiscalização, como por exemplo: Regularização fundiária ${ }^{18}$, fiscalização de áreas de fundeio ${ }^{19}$, diagnóstico e mapeamento das artes fixas ${ }^{20}$, campanhas de educação ambiental e colocação de placas nas ilhas, pesquisa sobre maricultura na enseada da Conceição $0^{21}$, além da proposta de fazer um programa de monitoramento da Baía de Ilha Grande, entre outras.

Em entrevista ${ }^{22}$, o então chefe da UC relatou que o objetivo da Estação é procurar identificar as atividades que estão sendo feitas nas áreas que a compõem e criar alternativas para se amenizar os diversos conflitos existentes. Para ele, a pesca seria apenas mais uma questão a ser resolvida, dada a complexidade de atividades e usuários da $\mathrm{BIG}$.

\subsection{Conflitos envolvendo pescadores arte- sanais e os "barcos de fora"}

Na Baía de Ilha Grande, os pescadores consideram "barcos de fora", as embarcações de pesca industrial oriundas de outras regiões do Rio de Janeiro (Baía de Guanabara, Baía de Sepetiba e Região dos Lagos), e de outros estados brasileiros, principalmente das regiões Sudeste (São Paulo) e Sul
(Santa Catariana e Rio Grande do Sul). Estas embarcações são de grande porte, utilizam tecnologias para detecção dos cardumes, como o ecossonda e o sonar, tecnologias estas consideradas por muitos pescadores como um problema/ameaça aos recursos pesqueiros.

Além do uso de tecnologias de detecção de cardume é também associado à pesca predatória (provocada pelo desrespeito ao defeso da sardinha e do camarão), à atuação de barcos em áreas protegidas no interior da baía, e à ausência de fiscalização ambiental.

Adicionalmente, o termo "barcos de fora” foi atribuído pelos pescadores, não somente às embarcações pesqueiras oriundas de outras regiões, mas também às embarcações que realizam as atividades ligadas ao setor de petróleo, gás e de turismo.

\subsubsection{Os atuneiros, cerqueiros e arrastões}

Na Baía de Ilha Grande é possível identificar conflitos entre as diversas modalidades de pesca, os quais mudam conforme a intensidade do método de captura, bem como o ambiente em que é praticado. Segundo o Plano de Manejo da APA de Cairuçu (IBAMA, 2004), em ambientes de interior da baía, por exemplo, predominam a rede de tresma-

18. As ilhas da Esec têm sido objeto de processos junto ao Ministério Público Federal, Serviço de Patrimônio da União e MMA.

19. Em entrevista, o então chefe da Esec Tamoios afirmou que, em fevereiro de 2013, foi realizada uma operação de fiscalização integrada, intitulada "operação âncora”. 0 objetivo da operação era fiscalizar áreas de fundeio.

20. Atualização do trabalho de identificação das pescarias (como o cerco flutuante) e dos cultivos (maricultura), iniciado há alguns anos, por um grupo de trabalho criado no âmbito da Câmara Técnica de Pesca e Aquicultura. Os resultados deste levantamento sugerem a existência de projetos que utilizam a atividade de maricultura como "fachada" para privatização de praias.

21. Trabalho desenvolvido em parceria com a Universidade do Estado do Rio de Janeiro e Associação dos Maricultores de Paraty (AMAPAR).

22. Entrevista realizada em 16 de março de 2010. 
lho, a rede de espera e o arrasto de fundo. A linha de mão, a rede de espera e o cerco flutuante, por outro lado, são predominantes em ambientes de mar aberto.

No que se refere ao conflito entre a pesca de pequeno e grande porte, os resultados do projeto GPESCA indicam que são comuns referências à pesca de vara com isca-viva, executada pela frota industrial atuneira, que captura peixes como o bonito listrado, albacora-laje, dourado e atuns, espécies que têm o hábito de se concentrarem em cardumes próximos à superfície. Este tipo de pescaria utiliza varas e anzóis para realizar a captura do pescado. Para atrair os cardumes, são lançados ao mar peixes vivos de pequeno porte, como a sardinha (as denominadas iscas-vivas), normalmente capturados em áreas costeiras.

As queixas dos pescadores da BIG recaem sobre a não penalização dessas embarcações pelos órgãos de fiscalização ambiental, por exercerem a captura da isca-viva da sardinha durante o período de defeso desta espécie e, principalmente, por pescarem em áreas no interior da baía. Por isso, parece ser consenso entre os pescadores da BIG, a necessidade de se criar um instrumento que possibilite limitar o acesso dos barcos de grande porte ao interior da baía (MPA/FIPERJ/UFRJ, 2010). Na percepção dos pescadores: "Os fiscais não punem os de fora, mas nós somos alvos frequentes"

Vale esclarecer, contudo, que os conflitos dessa natureza também estão associados à pescaria de sardinha realizada pela frota de cerco com embarcações do tipo traineiras, como segue: "Aqui todo mundo tem ódio de traineira...a sardinha que tá fora as traineira pega tudo e quando ela chega aqui, tá no defeso e aí a gente não pode pescar" 24 .

Há uma percepção generalizada de que não existe o mesmo tipo de rigor e controle sobre os "barcos de fora" e alegam haver necessidade de fazer valer as mesmas regras e punições sobre estas embarcações.

Os pescadores artesanais da BIG pescam, em grande medida, utilizando técnicas tradicionais, e não dispõem dos equipamentos que permitem capturas de sardinha e de camarão em níveis comparáveis aos "barcos de fora". Por isso, é muito comum os pescadores identificarem como um problema, o uso de tecnologias de detecção de cardumes tais como a sonda e o sonar, principalmente nas comunidades pesqueiras de Paraty. Para eles, este tipo de pesca não constitui uma pescaria legítima, tal qual estão acostumados a fazer, ou seja, tendo como base seus conhecimentos tradicionais, como segue: “Eles não pescam no olho, isso (numa referência à sonda) tem que tirar isso fora!" 25 . E ainda: "Em um mês os barcos de fora tiram do mar o que nós costumamos pescar em um ano"26.

Em parte, as queixas e reclamações do setor pesqueiro artesanal de que a fiscalização ambiental não é aplicada sobre os "barcos de fora", procedem. Em reunião ${ }^{27}$ realizada na Esec Tamoios, o então chefe da Unidade de Conservação afırmou ter difıculdades em realizar a fiscalização sobre os barcos de grande porte/industriais, como os

23. Pescador do Pouso da Cajaíba, entrevista concedida em 1 jul. 2011.

24. Pescador de Paraty entrevista concedida em 15 mar. 2010.

25. Pescador de Calhaus, Paraty, entrevista concedida em 1 jul. 2011.

26. Pescador de Ponta Grossa, entrevista concedida em 2 jul. 2011.

27. Reunião da Câmara Técnica de Aquicultura e Pesca, em 25 abr. 2012. 
atuneiros, já que a lancha que dispõe para as operações de fiscalização é pequena e não possui infraestrutura adequada para realizar ações desta natureza ${ }^{28}$.

Além do conflito envolvendo os atuneiros e cerqueiros que pescam em áreas abrigadas da Baía e durante o período de defeso da sardinha, também existem conflitos relacionados aos camaroneiros, que são embarcações que realizam o arrasto para a captura do camarão. Segundo o Ibama (2004), a ação ilegal e cada vez mais constante dos barcos da pesca comercial de camarão, através do arrasto de fundo em parelha, tangone ou popa, vem causando a diminuição gradativa dos recursos pesqueiros na Baía de Ilha Grande.

0 arrasto, assim como no caso da pesca de cerco, pode ser praticado tanto pela pesca industrial quanto artesanal. Na região da BIG, os pescadores artesanais costumam utilizar uma rede (arrasto simples) ou duas (arrasto duplo), variando conforme a potência do motor, sendo comumente utilizadas para a captura do camarão sete barbas. Um dos problemas identificados pelos pescadores locais é o de que essa modalidade de pescaria captura uma grande quantidade de pescado, já que apresenta baixa seletividade, além de extrair parte do assoalho marinho ${ }^{29}$.

Embora reconheçam o arrasto como uma arte de pesca altamente predatória, vale esclarecer que muitos pescadores ar- tesanais da região, principalmente os de Paraty, sobrevivem dessa prática. Contudo, eles atribuem o maior impacto à frota de arrasto industrial. Por isso, julgam necessário haver maior fiscalização, apesar de afirmarem que nos últimos anos foram obtidos alguns avanços após a atuação mais frequente do escritório regional do Ibama, sediado em Angra dos Reis. Os pescadores relatam que foi possivel observar, inclusive, o retorno e aumento da quantidade de peixes durante o defeso.

Apesar disso, reconhecem que o desrespeito ao defeso ainda é bastante presente na BIG como um todo. Os pescadores reconhecem que grande parte deles continua pescando no período onde a pesca é proibida, justificando esse tipo de prática por questões de sobrevivência e sustento familiar (principalmente quando relacionada à pesca de arrasto de camarão).

Os problemas/conflitos associados aos "barcos de fora" também estiveram relacionados às embarcações de turismo ${ }^{30}$, cargueiros e, principalmente, ao setor de petróleo e gás. Os pescadores queixam-se do aumento do tráfego de embarcações provocado pela presença de empreendimentos de grande porte na região e que circulam entre a Baía da Ilha Grande e o Porto de Sepetiba. Este aumento do fluxo de embarcações está relacionado à proximidade da região com a camada do pré-sal da Bacia de Santos,

28. Apesar das limitações técnicas e operacionais, vale ressaltar que em abril de 2013 foi realizada uma operação de fiscalização sobre uma embarcação de pesca de grande porte (atuneiro), que realizava cerco da sardinha em áreas da Esec Tamoios, nas proximidades da Ilha do Sandri.

29. Para cada $1 \mathrm{~kg}$ de camarão capturado pelo arrasto de fundo, por exemplo, $9 \mathrm{~kg}$ de organismos marinhos são mortos e devolvidos ao mar, sendo que 50\% das espécies capturadas, são juvenis em tamanho e peso e inferior ao permitido (IBAMA, 2004, p.141).

30. Os pescadores afirmam que, além da pesca artesanal e industrial, turistas também pescam camarões durante o período de defeso. Além disso, enfatizam a necessidade de se realizar pesquisas sobre a biologia reprodutiva da sardinha e do camarão, afirmando que é comum encontrar exemplares ovados, mesmo após o período de liberação da pesca. 
além da configuração geomorfológica do fundo da baía que permite que cargueiros e grandes petroleiros se aproximem muito da costa, minimizando os custos de carga e descarga do Terminal Petroleiro da Baía Ilha Grande - TEBIG.

Neste sentido, os pescadores mencionaram com certa frequência, as operações $s h i$ p-to-ship. Estas operações ocorrem quando dois navios localizam-se lado a lado para transferir cargas, como o petróleo bruto e seus produtos derivados, gás liquefeito, entre outros. Os pescadores temem pelo risco de vazamento de óleo relacionado à frequência, cada vez maior, de grandes embarcações que utilizam a região portuária e o TEBIG.

\subsection{Conflitos relacionados à regularização da atividade}

Para que possa exercer a pesca de forma legal, toda pessoa física ou jurídica que exerça a atividade pesqueira, bem como sua embarcação de pesca, devem estar inscritos no Registro Geral da Atividade Pesqueira - RGP, bem como no Cadastro Técnico Federal - CTF, na forma da legislação específica. 0 RGP é um instrumento de gestão do Governo Federal (Lei ${ }^{\circ}$ 11.959 de 2009), onde são inscritos os dados básicos de todos aqueles que, de forma licenciada, autorizada ou permissionada, exercem atividades relacionadas à pesca ou à aquicultura no Brasil. Esse processo se dá a partir da: (1) obtenção da carteira de pescador, documento que identifica o pescador; e (2) inscrição da embarcação de pesca para obtenção do Certificado de Registro e Licença Prévia de Pesca, onde constam os dados relativos à propriedade, posse, características estruturais e modalidade de permissionamento.

Os resultados encontrados pela pesquisa indicam que as licenças de pesca representam problemas para os pescadores da BIG, independentemente do tipo de pescaria; os problemas estiveram associados a diversas questões, entre elas dificuldade de acesso às licenças para espécies controladas.

\subsubsection{Dificuldade de acesso às licenças para espécies controladas}

A região da Baía de Ilha Grande tem como principais espécies-alvo das capturas, a sardinha verdadeira e os camarões. Ambas possuem alto valor comercial e são espécies controladas por legislação específica (MPA/FIPERJ/UFRJ, 2011). Por esta razão, as licenças para a captura do camarão e da sardinha não são emitidas com tanta frequência (frota controlada ${ }^{31}$ ), uma vez que constituem espécies que têm o seu esforço de pesca limitado.

Importante destacar que, na percepção dos pescadores, os "barcos de fora" (já descritos anteriormente) e/ou industriais estão, em sua maioria, regularizados, e as licenças para captura do camarão e da sardinha estariam "direcionadas" para esse tipo de frota. Segundo eles, isto configura "desigualdade de direitos”, provocando o acirramento dos conflitos inerentes à pesca artesanal e industrial, conforme trecho a seguir extraído de um pescador da comunidade de Ponta Grossa, Paraty: "Não fornecem a licença para o arrasto, isso dificulta a regularização de nossos barcos. Existe muita

31. A frota controlada" é o termo utilizado para se referir ao conjunto de embarcações autorizadas para atuar sobre espécies cujo esforço de pesca é limitado por ato normativo específico. Esta medida de ordenamento pesqueiro visa, principalmente, à recuperação e à manutenção dos estoques pesqueiros. 
burocracia, ela só funciona pra gente, pois os barcos grandes conseguem" ${ }^{32}$.

Em Angra dos Reis, por exemplo, boa parte da frota que atua na pesca de cerco da sardinha, conhecida como traineiras, não é permissionada. Embora este problema esteja relacionado principalmente à pesca industrial, a pesca da sardinha também é praticada por embarcações de menor porte, como o cerco flutuante (esta será descrita nas próximas seções).

\subsubsection{Burocracia e morosidade para a concessão/renovação das licenças}

Além das limitações relacionadas à dificuldade de acessar uma licença para espécie controlada, é importante mencionar também a pouca agilidade do sistema e a burocracia inerente à regularização da atividade. Neste aspecto, os pescadores queixam-se também da demora no recebimento do Registro Geral da Atividade Pesqueira - RGP e/ou renovação das licenças de pesca, e argumentam que também são exigidos muitos documentos nesse processo (MPA/ FIPERJ/UFRJ, 2010). A demora no recebimento do RGP pode comprometer, inclusive, o recebimento do seguro defeso, uma vez que para ter acesso ao mesmo, é preciso estar com toda a documentação atualizada.

Adicionalmente, os pescadores artesanais reclamam do prazo curto de validade das licenças (permissão prévia de pesca e autorização de pesca) e da ausência de superintendências regionais do órgão gestor da pesca e da aquicultura na região. Para dar entrada ao pedido e/ou renovação, por exemplo, os pescadores precisam se deslocar até a cidade do Rio de Janeiro, onde está localizada a sede do Escritório Federal da Aquicultura e Pesca. Como muitos desses pescadores moram em áreas rurais e/ou insulares afastadas do grande centro, alegam que o deslocamento até o Rio de Janeiro é bastante oneroso (seja em termos de tempo ou financeiro), e, em alguns casos, não conseguem dar prosseguimento ao processo, como explicitado no trecho a seguir: "Trabalho e sobrevivo da pesca, não tenho licença, já fiz de tudo para conseguir. Já disseram que tenho que ir no Rio de Janeiro. Eu não sei nem andar em Paraty, como que vou conseguir me virar no RJ?"33.

A desburocratização e a aproximação do órgão gestor da pesca na região, por meio de escritórios regionais, ou ainda, desenvolvendo ações itinerantes na região, são apresentadas pelos pescadores como saídas possíveis para se viabilizar esse tipo de demanda e sanar o estado de irregularidade em que se encontram.

\subsubsection{Embarcações com dupla classificação}

Outro problema identificado pelos pescadores consiste na dupla classificação que algumas embarcações dispõem. Conforme alguns estudos sugerem (IBIO, 2009; LOPES, 2010), o turismo também se apresenta como ocupação profissional importante para os pescadores da Baía de Ilha Grande, principalmente para aqueles de Paraty. Por isso, não é raro encontrarmos pescadores que direcionam também suas embarcações para a atividade de esporte/recreio, transportando turistas para as diversas ilhas e praias, por exemplo.

0 conflito ocorre porque, segundo os pescadores, embora muitos proprietários de 
embarcações optem por atuar na atividade turística, ainda assim são verificadas situações de recebimento do seguro defeso por parte destes, que é um benefício cedido ao pescador artesanal que vive exclusivamente da pesca, não dispondo de outra fonte de renda.

\subsubsection{Reconhecimento e ordenamento do} cerco flutuante e da pesca de camarão em botes e canoas

A pescaria de camarão em botes e/ou canoas a remo consiste em uma modalidade de pesca artesanal que vendo sendo praticada há muitas gerações pelos pescadores de Paraty. A pescaria é realizada por canoas e botes a remo que podem chegar até a $6 \mathrm{~m}$ de comprimento, utilizando apenas a força braçal.

Para a captura do pescado, são utilizadas redes de emalhar, conhecidas também como redes de espera. Neste sistema, os pescadores lançam suas redes ao mar, fazem a marcação com duas boias nas extremidades, e em seguida ficam aguardando o momento em que o peixe "malha". Além da rede de esmalhe, os pescadores locais costumam utilizar

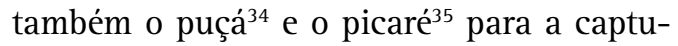
ra do camarão. Os pescadores direcionam a pesca principalmente para a captura do camarão branco (Litopenaeus schmitti) e camarão sete-barbas (Xiphopenaeus kroyeri), podendo também capturar peixes variados, sendo parte da produção destinada ao sustento da família e a outra parte vendida para complemento da renda familiar.

A captura do camarão em sistema de rede de emalhe, puçá e picaré não é permissionada ${ }^{36}$. Por serem recursos pesqueiros que têm seu esforço de pesca limitado/ controlado, os órgãos responsáveis pelo o ordenamento e gestão da pesca constantemente publicam leis e instruções normativas estabelecendo o período de defeso dessas espécies, assim como as normas de ordenamento dessas pescarias. Em alguns destes instrumentos legais, como é o caso da INI MPA/MMA N³/2011, estão estabelecidos apenas os critérios de pesca do camarão sete barbas para as embarcações motorizadas, não contemplando, portanto, as embarcações do tipo canoa e bote a remo (sem propulsão motorizada) ${ }^{37}$.

A não regularização desta modalidade de pesca emergiu como um problema/con-

34. Petrecho de pesca confeccionado com rede e ensacador, instalado em uma armação em forma de aro (CEPSUL/IBAMA, s/d).

35. 0 picaré é um pequeno arrasto de praia realizado por dois pescadores, podendo ser com ou sem funil (LOPES, 2010).

36. A permissão de pesca consiste num conjunto de informações relativas ao Método, à Modalidade de Pesca, com a(s) respectiva(s) espécie(s) a ser(em) capturada(s), incluindo a Fauna Acompanhante Previsível, a(s) Espécie(s) de Captura Incidental e a(s) Área(s) de Operação, componentes da Permissão Prévia de Pesca ou da Autorização de Pesca e da Autorização de Pesca Complementar (INI MPA/MMA n 10/2011). 37. Contudo, vale esclarecer que, embora esta legislação não contemple as embarcações sem propulsão a motor do tipo canoas e botes a remo, a INI MPA/MMA nº 3/2011 representa um avanço para o setor artesanal camaroneiro, uma vez que foram emitidas novas licenças do camarão sete barbas para as embarcações artesanais motorizadas que possuíam até $12 \mathrm{~m}$ de comprimento e que não haviam sido contempladas pela seleção ocorrida a partir da IN n ${ }^{\circ} 164 / 2007$. Esta última teria se limitado às embarcações permissionadas com comprimento igual ou inferior a $9 \mathrm{~m}$ de comprimento. Isso contribuiu para diminuir, ao menos em parte, os conflitos entre a pesca camaroneira artesanal e a industrial. 
flito para os pescadores locais quando da publicação da resolução $n^{\circ} 468 / 05$ do Conselho Deliberativo do Fundo de Amparo ao Trabalhador - CODEFAT. Esta resolução, posteriormente revogada pela Resolução $\mathrm{n}^{\circ}$ 657/2010, estabelece os critérios para a concessão do Seguro Desemprego aos pescadores artesanais durante os períodos de defeso.

O Seguro Desemprego é uma assistência financeira temporária destinada ao pescador profissional que exerça sua atividade de forma artesanal, individual ou em regime de economia familiar, ainda que com auxílio eventual de parceiros e que teve que interromper a atividade devido ao período de proibição da pesca para preservação da espécie (defeso) (Resolução n ${ }^{\circ}$ 657/2010). Esta Resolução estabelece uma série de procedimentos e critérios para os pescadores artesanais terem acesso ao benefício: uma delas consiste em ter o Registro como Pescador Profissional devidamente atualizado no Registro Geral da Pesca - RGP, classificado na categoria artesanal, emitido pelo órgão gestor da atividade, com antecedência mínima de 1 (um) ano da data do início do defeso.

Embora os pescadores já disponham da carteira de pescador (RGP), muitos possuem autorização/licença para capturar peixes e crustáceos diversos $^{38}$, não controlados por regulamentação específica. Em outras palavras, esses pescadores não estão autorizados a capturar espécies sob controle de esforço, como é o caso do camarão sete barbas (uma das espécie-alvo da pesca de canoas e botes a remo). 0 problema reside no fato de que, para ter acesso ao seguro defeso do camarão, é preciso ter licença específica para capturar este tipo de pescado que, conforme descrito anteriormente, consiste em uma espécie que tem esforço de pesca controlado e cujas licenças não são emitidas com tanta frequência. Como os pescadores de canoas e botes a remo ainda não foram reconhecidos e não dispõem de tal tipo de licenças/permissão de pesca, têm automaticamente este direito negado.

A falta de amparo legal para esta modalidade de pesca tem forçado os pescadores a trabalharem na ilegalidade, já que eles continuam pescando para fins de sobrevivência e sustento de suas famílias. Como resultado, acabam sendo autuados pelos órgãos de fiscalização por pescarem o camarão em período de defeso e sem a respectiva licença, correndo o risco de ser presos e/ou multados, além de ter seu material de pesca apreendido.

Considerando que a falta de reconhecimento dessa modalidade de pesca vem colocando em cheque os pequenos pescadores artesanais perante a fiscalização ambiental, podendo eles, ser submetidos à autuação e ter sua embarcação e seus petrechos de pesca confiscados levando a ser enquadrados como criminosos ambientais, conforme o que dispõe a Lei 9.605/95 da política nacional de práticas lesivas ao meio ambiente, por falta de um amparo legal" (MOÇÃO do Conselho Municipal de Política Agrícola e Pesqueira de Paraty, no 01, de 10 de setembro de 2009).

Por conta disso, não é raro encontrar pescadores que costumam fazer "acordos"

38. Segundo a INI MPA/MMA No10/2011, que dispõe sobre as normas gerais e a organização do sistema de permissionamento de embarcações, a pescaria praticada pelos pescadores da região é classificada como "Diversificada Costeira”, ou seja, aquela praticada por embarcações de pequeno porte, com propulsão a remo ou a vela, e, quando motorizadas, com potência de motor até 18hp, comprimento até $8 \mathrm{~m}$ e arqueação bruta até 2,0 . 
com proprietários das embarcações regularizadas para obtenção do seguro defeso. Para que isto seja possível, são recolhidos todos os documentos necessários do requerente e o dono da embarcação atestada ao Ministério do Trabalho e Emprego (que até a realização desta pesquisa era a instituição responsável pelo pagamento do seguro defeso do pescador artesanal) de que aquele pescador trabalha em regime de parceria na embarcação que dispõe da licença para a captura da espécie do defeso em questão. Em contrapartida, os pescadores afirmam que, em alguns casos, é comum os pescadores beneficiados pelo seguro repassarem metade do benefício ao proprietário.

De maneira similar à pescaria de emalhe, a pescaria de cerco flutuante também é realizada por canoas e botes a remo. Entretanto, o cerco flutuante consiste em um aparelho de pesca fixado ao fundo do mar por meio de âncoras, normalmente em entradas de baías profundas. 0 cerco funciona 24 horas por dia, capturando e mantendo vivos os cardumes que, ao migrarem para a zona costeira, adentram o aparelho e não conseguem mais sair (SECKENDORFF; AZEVEDO; MARTINS, 2009). Os cercos são posicionados em locais estratégicos, conhecidos pelos pescadores como "de passagem dos peixes”, especialmente para captura dos peixes que se deslocam à meia água. $\mathrm{A}$ técnica objetiva a captura de cardumes de pelágicos, tais como cavala, enxova, carapau, olhete e outros (IBAMA, 2004).

Dados contidos no Plano de Manejo da APA de Cairuçu indicaram a existência de 52 pontos de cercos flutuantes, sendo 37 entre a Ponta da Cajaíba e a Ponta da Trindade, e 15 pontos espalhados nos ambientes de interior da Baía de Ilha Grande. Segundo este levantamento, é possível constatar uma enorme dependência do cerco flutuante pelas comunidades de pescadores que habitam os ambientes sob influência do mar aberto, sendo que inúmeras famílias subsistem dessa produção, como as das comunidades da Cajaíba Calhaus, Joatinga, Enxovas, Cairuçú das Pedras, Ponta Negra e Sono (IBAMA, 2004).

Segundo parecer técnico da FIPERJ, contido em um Processo ${ }^{39}$ da SFPA-RJ/ MPA, as primeiras regulamentações para o cerco flutuante datam de 1983 (Decreto-Lei $n^{\circ} 794 / 1983$ ) e de 1941 (Portaria $n^{\circ}$ 39/1941) da Divisão de Caça e pesca do estado do Rio de Janeiro. A legislação mais recente é a IN MMA n ${ }^{\circ}$ 14/2005, que dispõe sobre os critérios para o uso de artes de pesca fixas, conhecidas como cercadas, currais, estacadas, marcas de barragens, tribobós e ganchos utilizadas em lagunas, enseadas e baías do estado. Segundo este documento, as artes fixas contidas nesta legislação são comumente encontradas Baía de Sepetiba, Baía da Guanabara e Região dos Lagos (Lagoa de Araruama), não contemplando as artes fixas da BIG, que possuem estruturas diferenciadas das contidas na referida Instrução Normativa.

Por não existirem ainda normas específicas para a arte de pesca fixa conhecida como cerco flutuante, os pescadores que realizam esta pescaria encontram dificuldades de licenciamento. Por ser uma pescaria não permissionada pelo MPA, os pescadores ficam impossibilitados de ter acesso às principais políticas públicas, como a do seguro-desemprego durante o defeso. de modalidade de pesca tipo "cerco de peixes flutuantes". 


\subsection{As manifestações do setor pelo reco- nhecimento das pescarias}

Durante o período compreendido entre os anos de 2006 até 2011, o setor pesqueiro de Paraty, representado principalmente pela Colônia de Pescadores Z-18 e Câmara Municipal de Vereadores, passou a promover diversas ações visando o reconhecimento da pesca em canoas e botes a remo como modalidade de pesca, para fins de licenciamento. Neste sentido, foram encaminhados ofícios e feitas moções para diversos órgãos ligados à gestão dos recursos pesqueiros municipais e federais, tais como: Agência da Capitania dos Portos em Paraty, Conselho Municipal de Política Agrícola e Pesqueira de Paraty, Secretaria Municipal de Pesca e Agricultura de Paraty e Prefeitura Municipal, MPA, CEPSUL, MTE, MMA, Diretoria de Recursos Pesqueiros do IBAMA - Brasília, Câmara Técnica de Aquicultura e Pesca da Esec Tamoios, entre outros.

Uma das primeiras iniciativas com o propósito de reconhecimento foi a articulação feita pela Colônia Z-18 de Paraty junto à Capitania dos Portos do município, para que o órgão viabilizasse o registro de embarcações miúdas ${ }^{40}$ sem propulsão a motor ${ }^{41}$.
A necessidade do registro gerou um impasse, que se deveu ao fato do órgão gestor da pesca exigir, para fins de licenciamento, cópia do Título de Inscrição de Embarcação (TIE) junto à Capitania dos Portos. Na época em que o trabalho de campo desta pesquisa foi realizado, tal exigência representava um problema para os pescadores no momento da regularização junto ao extinto MPA, já que a Capitania dos Portos dispensava de inscrição, as embarcações miúdas sem propulsão (NORMAM 02/DPC). Entretanto, em 2011 foi realizado um acordo entre esses dois órgãos para que a Marinha passasse a realizar a inscrição das embarcações miúdas da pesca artesanal.

Outro marco neste processo refere-se à aprovação de uma Moção, em 2009, no âmbito do Conselho Municipal de Política Agrícola e Pesqueira de Paraty, solicitando apoio para o reconhecimento da modalidade de pesca de canoas e botes a remo, para fins de licenciamento. A partir deste momento, a Câmara Municipal de Paraty começa a pressionar o governo municipal para pleitear, junto ao ex-MPA, o reconhecimento e permissionamento dessas canoas e botes ${ }^{42}$. No mesmo ano, são encaminhados ao Ministério da Pesca e Aquicultura

40. São consideradas embarcações miúdas, qualquer tipo de embarcação ou dispositivo flutuante: 1) Com comprimento inferior ou igual a cinco (5) metros; ou 2) Com comprimento total inferior a $8 \mathrm{~m}$ e que apresentem as seguintes características: convés aberto, convés fechado, mas sem cabine habitável e sem propulsão mecânica fixa e que, caso utilizem motor de popa, não deve exceder 30 HP (NORMAM-02/DPC). Além da NORMAM 02, a INI MMA/MPA, n¹0/2011 define que as embarcações miúdas são: “embarcações de pesca não motorizadas com $\mathrm{AB}$ inferior ou igual a 2. Na ausência de informações sobre a $\mathrm{AB}$, a embarcação deverá possuir comprimento igual ou inferior a $8 \mathrm{~m}$, sem propulsão a motor. Quando for motorizada, a potência do motor não poderá ultrapassar 18Hp" (INI MMA/MPA, nº10/2011).

41. Esta demanda surgiu inicialmente, devido ao processo de recadastramento dos pescadores e de suas embarcações junto à extinta Secretaria especial de Aquicultura e Pesca - SEAP (Ofício Colônia Z-18 $\left.\mathrm{N}^{\circ} 24 / 2006\right)$.

42. No mesmo ano, a Secretaria de Agricultura e Pesca de Paraty e Prefeitura Municipal manifestaram apoio ao pleito do setor pesqueiro e Câmara de Vereadores do município (Ofícios Prefeitura Municipal de Paraty $n^{\circ} 27 / 2009$ e $\left.n^{\circ} 256 / 2009\right)$. 
diversos requerimentos ${ }^{43}$ aprovados em Sessão Ordinária, solicitando apoio dessa instituição, bem como a abertura de processo administrativo (municipal e federal).

De maneira geral, os documentos trazem informações sobre essa modalidade de pesca e procuram destacar a relevância social, cultural e econômica para os pescadores artesanais de Paraty. Além disso, são também descritos os problemas e conflitos gerados pelo não permissionamento desta modalidade de pescaria, conforme trecho a seguir:

0 não permissionamento desta categoria vem causando um grande descontentamento no setor pesqueiro artesanal de Paraty, pois boa parte destas embarcações artesanais já atua há muitos anos na pesca, o que é passado de geração para geração, de pai para filho, e lamentavelmente, as autoridades competentes não reconhecem esta modalidade de pesca até o presente momento, e até hoje, o setor pesqueiro de Paraty, nunca entendeu por que esta classe nunca foi reconhecida dignamente. É sabido e notório saber que estas pequenas embarcações além de exercerem a pesca de forma artesanal e racional, agregam grandes valores para o município de Paraty, através da geração de emprego e renda, fomentando os pequenos pescadores do nosso município, sem comprometer o estoque pesqueiro pela sua forma de pescaria de baixo impacto ambiental, mas para tanto, precisam ser reconhecidos (Requerimento $\mathrm{n}^{\circ}$ 64/2009, Câmara Municipal de Paraty).

Durante os anos de 2010 e 2011 continuaram sendo envidados esforços, princi- palmente por parte da Câmara Municipal de Paraty, no que se refere ao reconhecimento dessas pescarias. Foi somente em novembro de 2011 que a Superintendência Federal da Pesca e da Aquicultura do Rio de Janeiro - SFPA-RJ encaminhou um processo ao MPA/PR (presidência), solicitando o seu reconhecimento. No processo, é solicitado o permissionamento de: “embarcações de pequeno porte (comprimento até $8 \mathrm{~m}$ e arqueação bruta até 2), com propulsão a remo, a vela, ou com motor, de potência até $18 \mathrm{hp}$, na captura das espécies de camarão branco e cinza em sistema de rede de emalhe, puçá e picaré". 0 processo contém 113 páginas e até a conclusão deste estudo, encontrava-se em análise junto ao MPA/PR.

De maneira similar, também foram expedidos diversos ofícios ao então MPA e demais órgãos responsáveis pelo gerenciamento dos recursos pesqueiros solicitando a regularização da pescaria de cercos flutuantes em Paraty, já que a pesca de cerco flutuante também é realizada por canoas e botes a remo.

Os documentos compõem o Processo instituído pela Superintendência Federal da Pesca e da Aquicultura no estado do Rio de Janeiro (SFPA-RJ/MPA) junto ao órgão em Brasília ${ }^{44}$. 0 referido processo solicita a "criação de normas para a regularização da modalidade de pesca de cerco de peixe flutuante". Além disso, o documento sugere a implementação de um diagnóstico e a definição da capacidade de suporte para o cerco flutuante na região $\mathrm{SE} / \mathrm{S}$, recomendando também a publicação de uma norma específica para a sua regulamentação no estado do Rio de Janeiro. 


\section{Considerações finais}

Conforme exposto neste artigo, a pesquisa agrupou quase todos os problemas em três grandes vertentes de conflitos relacionados aos pescadores artesanais, como tentativa de dar subsídios à sua caracterização: (1) sobreposição de territórios de pesca/ pesqueiros e as áreas protegidas, principalmente aqueles relacionados à Esec Tamoios; (2) conflitos associados à pesca industrial, identificados pelos pescadores como "barcos de fora” e, em menor escala, às embarcações de petróleo/gás e do turismo e; (3) conflitos resultantes pela falta de regularização/permissionamento da atividade.

Os conflitos relacionados às áreas protegidas na Baía de Ilha Grande representam, paradoxalmente, uma das principais restrições à permanência da pesca artesanal na região, ao mesmo tempo em que também constituem importantes espaços de manutenção da biodiversidade e dos recursos pesqueiros. Vale lembrar também que as restrições no tocante ao acesso e uso das áreas marinhas são agravadas por uma legislação de ordenamento pesqueiro que se sobrepõem com as áreas delimitadas pela Esec Tamoios. Este choque de normas sugere a necessidade de se fazer uma atualização da legislação incidente sobre a Baía, de maneira a subsidiar medidas de ordenamento do espaço marinho, a exemplo do zoneamento ecológico econômico.

0 uso de tecnologias de detecção de cardume, tais como a sonda e o sonar, são consideradas, pelos pescadores artesanais, como uma ameaça à sustentabilidade dos recursos pesqueiros. Isto se deve ao fato desses trabalhadores pescarem, em grande medida, utilizando seus conhecimentos tradicionais, evidenciando o que Diegues (1983) denomina como uma cultura própria de "saber-fazer", de pescar e de conhecer a natureza, a qual é carregada de simbolismos. Este conflito esteve associado também à pesca predatória, provocada pelo desrespeito ao defeso da sardinha e do camarão. Sobre este aspecto, vale esclarecer que os próprios pescadores artesanais assumem também praticar a pesca ilegal durante 0 defeso, justificando esta irregularidade para fins de sobrevivência. A pesca predatória atribuída aos "barcos de fora" esteve também associada à atuação destes barcos em áreas protegidas e à ausência de fiscalização ambiental.

Por fim, vimos que os conflitos resultantes da falta regularização/permissionamento dos pescadores e de suas embarcações tem deixado os pescadores vulneráveis à fiscalização, além de dificultar o acesso às políticas públicas, como o defeso. Por isso, uma das principais demandas do setor pesqueiro artesanal da região consiste no reconhecimento e ordenamento da pesca de camarão em botes e canoas a remo, e da pesca de cerco flutuante. Vale destacar que esse problema só emergiu como um conflito, quando os pescadores não conseguiram ter acesso ao seguro defeso. A falta de amparo legal tem forçado esses pescadores a trabalhar na ilegalidade, já que continuam pescando para fins de sobrevivência e sustento de suas famílias.

Embora os conflitos envolvendo segmentos da pesca artesanal e industrial não constituam um conflito inédito no cenário da pesca nacional, no que se refere especificamente aos conflitos envolvendo as áreas protegidas, estes talvez carreguem maior peso simbólico, em especial aos pescadores da BIG. Embora a UC já existisse há alguns anos, os pescadores artesanais sentiriam os efeitos de sua criação, especialmente quando a Esec Tamoios iniciou suas 
atividades de fiscalização no mar, por volta de 2006-2007. Foi a partir deste momento que começaram a se dar as primeiras manifestações públicas em reação às operações de fiscalização e à organização do setor diante do problema ${ }^{45}$. Consequentemente, há um acúmulo de demandas e conflitos envolvendo o setor, os quais se tornaram o foco das atenções de ONG's, universidades e instituições de pesquisa/extensão.

Todo esse acúmulo institucional relatado começava a dar as primeiras pistas sobre a necessidade de se pensar formas alternativas de gestão e mediação dos conflitos envolvendo, particularmente, os pescadores artesanais e caiçaras, um dos grupos sociais mais vulneráveis neste cenário de crescimento desordenado, os quais vêm sofrendo diretamente os impactos da desapropriação do mar e de seus recursos naturais.

\section{Referências}

ACSELRAD, H. Conflitos ambientais no Brasil. Rio de Janeiro: Relume Dumará; Fundação HeirichBoll, 2004.

- Apresentação. In: ZHOURI, A.; LASCHEFSKI, K.; PEREIRA, D. (Orgs.). A insustentável leveza da política ambiental: desenvolvimento e conflitos ambientais. Belo Horizonte: Autêntica, 2005, p. 7-9.

BEGOSSI, A.; LOPES, P. L.; OLIVEIRA, L. E. C.; NAKANO, H. Ecologia de pescadores artesanais da Baía de Ilha Grande. São Carlos: RiMa, FAPESP, 2010.

CARNEIRO, E. J. Politica ambiental e ideologia do desenvolvimento sustentável. In: ZHOURI, A.; LASCHEFSKI, K.; PEREIRA, D. (Orgs.). A insustentável leveza da política ambiental: desenvolvimento e conflitos ambientais. Belo Horizonte: Autêntica, 2005, p. 27-47.

CREED, J. C.; PIRES, D. 0.; FIGUEIRED0, M. A. 0. Biodiversidade marinha da Baía de Ilha Grande. Brasília: MMA/SBF, 2007.
DIEGUES, A. C. A mudança como modelo cultural: o caso da cultura caiçara e a urbanização. In: DIEGUES, A. C. (Org.). Enciclopédia caiçara: o olhar do pesquisador. São Paulo: HUCITEC; NUPAUBCEC/USP. 2004, p. 21-48.

Pescadores, camponeses e trabalhadores do mar. São Paulo: Atlas, 1983.

IBAMA. Instituto Brasileiro do Meio Ambiente e dos Recursos Naturais Renováveis. Plano de Manejo APA Cairuçu. 2004. 127p. Encarte I - Caracterização Ambiental.

IBAMA. Instituto Brasileiro do Meio Ambiente e dos Recursos Naturais Renováveis. Plano de Manejo da Estação Ecológica de Tamoios. Brasília, 2006. 20p. Fase I- Informações gerais da UC.

IBIO. Instituto Bioatlântica. Projeto Mares da Ilha Grande: conservando em rede. Rio de Janeiro: Instituto BioAtlântica. 79p. 2009.

ICMBio. Instituto Chico Mendes de Conservação da Biodiversidade. Um ano de monitoramento das atividades humanas em áreas da Estação Ecológica de Tamoios: a baía de Ilha Grande suporta uma unidade de conservação de proteção integral? Paraty, 2009. 81 p. Relatório técnico.

JOVENTINO, F. K. P. Pesca artesanal na Baía de Ilha Grande, RJ: conflitos e novas possibilidades de gestão compartilhada. 2013. $234 \mathrm{f}$. Tese (Doutorado em Construção Social do Meio Ambiente) - Programa de Pós-Graduação em Meio Ambiente. Rio de Janeiro: Universidade do Estado do Rio de Janeiro/UERJ, Rio de Janeiro, 2013.

LITTLE, P. E. Ecologia política como etnografia: um guia teórico e metodológico. Horizontes Antropológicos, v. 12, n. 25, p. 85-103, 2006.

Os conflitos socioambientais: um campo de estudo e de ação política. In: BURSZTYN, M. (Org.). A difícil sustentabilidade: política energética e conflitos ambientais. Rio de Janeiro: Garamond, 2001, p. 107-122.

LOPES, P. F. Uso de recursos naturais. In: BEGOSSI, A. L.; LOPES, P.; OLIVEIRA, L. E.; NAKANO, H. (Orgs.) Ecologia de pescadores artesanais da Baía 
de Ilha Grande. São Carlos: RiMa, FAPESP, 2010.

MARTÍNEZ-ALIER, J. O Ecologismo dos pobres: conflitos ambientais e linguagens de valoração. São Paulo: Contexto, 2007.

MMA. Ministério do Meio Ambiente. Plano Estratégico Nacional de Áreas Protegidas - PNAP. Decreto $n^{\circ}$ 5.758, de 13 de abril de 2006. Brasília, 2006.

MMA. Ministério do Meio Ambiente. Biodiversidade brasileira: avaliação e identificação de áreas e ações prioritárias para conservação, utilização sustentável e repartição de benefícios da biodiversidade nos biomas brasileiros. Relatório de ações e avaliação. Brasília: MMA/SBF, 2002, 404p.

MPA, FIPERJ, UFRJ. Desenvolvimento e gerenciamento de sistemas de gestão da aqüicultura e pesca na Baia de Ilha Grande (Acordo de PescaBIG). Rio de Janeiro, 2010. Projeto básico.

MPA, FIPERJ, UFRJ. Desenvolvimento e gerenciamento de sistemas de Gestão da aqüicultura e pesca na Baía de Ilha Grande (Acordo de PescaBIG). Rio de Janeiro, 2011. Relatório parcial.

PEREIRA, D. B. Paradoxos do papel do Estado nas Unidades de Conservação. In: ZHOURI, A.; LASCHEFSKI, K.; PEREIRA, D. (Orgs.). A insustentável leveza da política ambiental: desenvolvimento e conflitos ambientais. Belo Horizonte: Autêntica, 2005, p. 119-142.

PRAD0, R. M. A beleza traída: percepção da usina nuclear pela população de Angra dos Reis. Antropolítica, v. 13, p. 137-160, 2002.

SECKENDORFF R. W.; AZEVEDO, V. G.; MARTINS, J. K. Sobre a técnica construtiva da arte de pesca de cerco flutuante no litoral norte de São Paulo. Instituto de Pesca. São Paulo, n. 40, maio/2009. 16p. (Série Relatórios Técnicos). 
RESUMO

Este artigo apresenta os principais conflitos envolvendo a pesca artesanal na Baía de Ilha Grande - BIG, no estado do Rio de Janeiro. A metodologia envolveu a observação direta em reuniões relacionadas a conselhos consultivos e grupos de trabalho em unidades de conservação, além de apresentações públicas sobre a proposta de "Acordos de Pesca" e audiências públicas (entre julho de 2010 a abril de 2013). De forma complementar, a pesquisa se baseou em uma extensa e vasta análise documental, além de entrevistas. Os conflitos foram caracterizados em três grandes categorias: i) resultantes da sobreposição dos pesqueiros e áreas protegidas; ii) associados aos "barcos de fora"; e iii) resultantes da falta de regularização/ permissionamento. Em síntese, esses conflitos envolvem políticas de desenvolvimento e de conservação, que se confrontam com o modo de vida tradicional dos pescadores artesanais e caiçaras, além do papel paradoxal do Estado no estabelecimento das regras e normas de ordenamento.

\section{PALAVRAS-CHAVE}

Conflitos. Pesca artesanal. Baía de Ilha Grande. Rio de Janeiro.

\section{ABSTRACT}

The article presents the main conflicts involving artisinal fisheries in the Ilha Grande Bay, in the state of Rio de Janeiro, Brazil. The methodology comprised the direct observation of meetings of the consulting councils and working groups in conservation units, and also public events related to the Fisheries Agreement. The research has also drawn on extensive document analysis and interviews. The conflicts were characterized in three major categories: i) those resulting from the overlapping between fishing and protected areas; ii) conflicts associated with large-scale fishing and, to a smaller degree, with oil and gas ships and touristic boats; and iii) conflicts due to the lack of regularization/allowance of the activity. In short, these conflicts comprise development and conservation policies which In sum, these conflicts involve both development and conservation policies, which at all times contradict the traditional lifestyle of artisanal fishermen and caiçaras. Besides resulting from different forms of use of the sea, these conflicts are also related to the paradoxical role of the state in setting rules (including supervision and environmental monitoring) to the bureaucracy and to several institutions dedicated to common problems.

\section{KEYWORDS}

Conflicts. Small-scale fisheries. Ilha Grande Bay. Rio de Janeiro.

Recebido em: 09.03.17

Aprovado em: 13.06.18 
